\title{
OPINI GOING CONCERN: DITINJAU DARI AGENSI TEORI DAN PEMICUNYA
}

\author{
I Dewa Made Endiana \\ Ni Nyoman Ayu Suryandari \\ endixdr@yahoo.com \\ Universitas Mahasaraswati Denpasar
}

\begin{abstract}
The continuity of a company can be identified from its financial report issued by auditors. Company's ability in fulfilling its obligation is one of the crucial factors for the company to keep its existence in this tough competition. Therefore, this research journal aims to determine the effects on the firm size, the firm development, debt to equity ratio, audit quality, the previous year's audit opinion on the tendency of acceptance of going-concern audit opinion in manufacturing companies registered on the Indonesia Stock Exchange.Using the data population of 165 registered manufacturing companies on the Indonesia Stock Exchange from 2016 to 2019, applying purposive sampling data analysis technique, resulted to 68 units of manufacturing companies as research samples per year and becoming 272 research samples for 4 years. The applied Data Analysis method is Logistic Regression Analysis.From the results of the hypothesis test the obtained results are that the company's size, company's development had negative effect the tendency of going concern audit opinion. Debt to equity ratio did not effect the tendency of going concern audit opinion. But audit quality, and the previous year's audit opinion had possitive affect the tendency of going concern audit opinion.
\end{abstract}

Key words: size, growth, going concern, debt to equity ratio, audit quality

\begin{abstract}
ABSTRAK
Kontinuitas perusahaan dapat diidentifikasi dari laporan keuangannya yang dikeluarkan oleh auditor. Kemampuan perusahaan dalam menyelesaikan kewajibannya merupakan hal yang diperhatikan oleh perusahaan untuk mempertahankan eksistensinya dalam persaingan yang ketat ini. Ini menjadi hal yang sangat penting untuk diperhatikan. Oleh karena itu, penelitian ini memiliki tujuan untuk mengetahui pengaruh pada ukuran perusahaan, perkembangan perusahaan, rasio hutang terhadap ekuitas, kualitas audit, opini audit tahun sebelumnya pada kecenderungan penerimaan opini audit going concern di perusahaan manufaktur yang terdaftar di Bursa Efek Indonesia. Menggunakan populasi data dari 165 perusahaan manufaktur terdaftar di Bursa Efek Indonesia dari 2016 hingga 2019, menggunakan teknik sampling yaitu purposive sampling, menghasilkan 68 unit perusahaan manufaktur sebagai sampel dan dengan jumlah amatan sebanyak 272 selama 4 tahun. Teknik Analisis Data yang digunakan adalah Analisis Regresi Logistik. Dari hasil analisis menunjukkan hasil bahwa ukuran perusahaan, pertumbuhan perusahaan berpengaruh negatif terhadap opini audit going concern. Rasio hutang perusahaan tidak mempengaruhi pemberian opini audit going concern. Sedangkan kualitas audit, dan opini audit periode sebelumnya berpengaruh positif pada kecenderungan pemberian opini audit going concern.
\end{abstract}

Kata kunci: Ukuran, Pertumbuhan, Kelangsungan Hidup, Rasio Hutang terhadap Ekuitas, Kualitas Audit

\section{PENDAHULUAN}

Kondisi ekonomi saat ini dengan persaingan yang ketat, menuntut dunia usaha harus memperhatikan keberlangsungan hidupnya. Perusahaan yang siap menghadapi persaingan yang akan mampu bertahan. Dengan kondisi demikian, perusahaan harus memiliki strategi dan tata kelola yang baik 
sehingga efektivitas perusahaan terjaga sehingga mampu bertahan dalam persaingan. Perusahaan dalam menjaga keberlangsungan operasional perusahaan, dihadapkan pada seringnya ada potensi perbedaan kepentingan antara manajemen dan pemegang saham. Potensi konflik ini kalau tidak mampu dikelola dengan baik akan berpotensi mengancam keberlangsungan perusahaan. Manajemen dalam melaksanakan operasional memiliki kebijakan dan strategi dan terkadang itu berbeda dengan kepentingan yang dimiliki oleh pemegang saham. Keberlangsungan hidup (going concern) merupakan salah satu penilaian dari auditor independen terhadap keberlangsungan perusahaan.

Publik menilai perusahaan dilihat dari potensi dan peluang perusahaan bisa bertahan dalam persaingan bisnis yang sangat ketat. Berbagai indikator kinerja keuangan perusahaan dapat menjadi pertimbangan terkait kondisi perusahaan. Investor atau calon investor tentunya akan mengambil keputusan untuk berinvestasi dengan membeli saham pada perusahaan yang dianggap mampu mendapatkan laba dan memiliki keberlangsungan hidup yang panjang. Hasil opini audit terkait keberlangsungan hidup perusahaan juga sangat penting dilihat oleh publik sebelum memutuskan untuk melakukan investasi.

Berbagai hal yang dapat menyebabkan auditor memberikan opini going concern yaitu: adanya kendala yang mengakibatkan auditor tidak menyampaikan status keberlangsungan hidup perusahaan karena auditor memandang jika opini audit going concern yang disampaikan bisa mempercepat kemunduran perusahaan yang memang memiliki permasalahan. Tetapi opini going concern harus tetap disampaikan sehingga perusahaan dengan segera dapat melakukan perbaikan atas kondisi keuangan perusahaan. Hal tersebut merupakan sisi positif manajemen dan pemegang saham mengetahui kondisi perusahaan.

Berdasarkan pengalaman bahwa banyak terdapat kejadian memanipulasi lapo- ran keuangan dilakukan oleh perusahaan besar yang sampai berakibat bangkrut. Hal ini tentunya dapat merugikan pemegang saham ataupun pihak-pihak yang ada hubungan finansial dengan perusahaan. Dengan kejadian demikian, maka penyampaikan pendapat terkait keberlangsungan perusahaan sangat bermanfaat bagi semua pihak yang berhubungan secara finansial kepada perusahaan.

Hal-hal yang dapat dipertimbangkan oleh auditor dalam memberikan pendapat terkait bekerlangsungan hidup perusahaan meliputi terkait ukuran perusahaan, Perumbuhan perusahaan, dan debt equity ratio, ada juga faktor eksternal perusahaan seperti kualitas auditor dan opini audit tahun sebelumnya. Rakatenda dan Putra ( 2016) mengungkapkan bahwa ukuran perusahaan berpengaruh negatif terhadap penerimaan opini audit going concern. Perusahaan yang besar, peluang untuk memperoleh keuntungan dari aktiva yang dimiliki dan juga sumber pendanaan yang berasal dari eksternal, sehingga kebelangsungan perusahaan akan lebih terjamin.

Pertumbuhan perusahaan dapat dijadikan acuan suatu perusahaan bisa tetap survive atau tidak untuk periode berikutnya. Pertumbuhan perusahaan menggambarkan kondisi perusahaan yang berkembang baik dari sisi asset maupun dari sisi pertumbuhan penjualan. Dengan kondisi demikian, maka perusahaan yang sedang mengalami partumbuhan akan cenderung mengalami kestabilan dalam posisi keuangan. Hal ini tentunya berdampak pada keberlangsungan operasional perusahaan menjadi lebih terjamin. Jika auditor melihat pertumbuhan perusahaan cenderung meningkat, maka auditor tidak akan memberikan pendapat terkait going concern. Pratiwi dan Lim (2018) mengungkapkan bahwa pertumbuhan perusahaan berpengaruh positif terhadap penerimaan opini audit going concern. Sedangkan menurut Putra et al. (2017) yang menunjukkan bahwa pertumbuhan perusahaan berpengaruh negatif terhadap penerimaan opini audit going concern. 
Faktor lain yang dipertimbangkan oleh auditor adalah terkait opini audit tahun sebelumnya. Pendapat auditor pada audit periode sebelumnya menjadi salah satu acuan dan pertimbangan auditor dalam memberikan pendapat terkait keberlangsungan hidup perusahaan. Wati et al. (2017) menyatakan bahwa opini audit tahun sebelumnya berpengaruh positif terhadap penerimaan opini audit going concern. Pendapat auditor pada periode sebelumnya dapat dijadikan pertimbangan auditor di dalam memberikan pendapat tentang keberlangsungan perusahaan karena bagaimanapun juga opini audi tahun sebelumnya menunjukkan kondisi perusahaan.

Kualitas auditor ini umumnya dilihat dari auditor tersebut apakah berasal dari KAP big four atau tidak. Auditor yang berada pada KAP big four akan memiliki kualitas yang dapat dipertanggungjawabkan. Penelitian Fahmi (2015) menyatakan bahwa kualitas auditor berpengaruh negatif terhadap opini audit going concern. Hasil yang berbeda ditunjukkan oleh Nafiatin (2017) yang menemukan bahwa kualitas audit berpengaruh positif terhadap penerimaan opini audit going concern.

Faktor lain yang juga menjadi pertimbangan auditor dalam memberikan pendapat terkait keberlangsungan hidup perusahaan adalah menyangkut kemampuan membayar hutang. Kegagalan membayar hutang dianggap sebagai faktor yang mempengaruhi opini audit going concern oleh auditor. Jika jumlah hutang perusahaan besar, maka arus kas perusahaan dominan dipakai untuk menutupi hutang sehingga berpotensi mengganggu keseimbangan operasi perusahaan. Perusahaan harus mampu mengelola sumber pendanaan dari luar perusahaan (hutang) sehingga dapat dipergunakan untuk memaksimalkan keuntungan yang diperoleh perusahaan. Kegagalan memanfaatkan peluang memperoleh keuntungan dari aktivitas pendanaan perusahaan akan memicu potensi kegagalan dalam membayar kewajiban kepada pihak ketiga. Hal ini yang mempengaruhi likuiditas perusahaan. Jika hutang ini tidak diselesaikan, maka kreditor akan menganggap perusahaan tidak bisa menunaikan kewajibannya. Status gagal bayar dapat meningkatkan mencermintan perusahaan ada dalam masalah likuiditas. Kondisi permasalahan likuiditas akan meningkatkan kemungkinan auditor mengeluarkan laporan audit going concern (Kusumaningrum dan Zulaikha, 2019). Al Fath dan Sugito (2020) menyatakan default tidak berpengaruh terhadap opini audit going concern. Berdasarkan hasil dari penelitian sebelumnya yang menunjukkan hasil yang tidak konsisten, maka sangat relevan diadakan penelitian untuk mengetahui faktor internal dan eksternal yang mimpengaruhi kecenderungan penerimaan opini audit going concern. Penelitian ini mengambil kasus pada perusahan manufaktur selama periode 2016 sampai dengan 2019.

Sesuai dengan penjelasan yang telah disampaikan, maka timbul ketertarikan untuk melakukan pengujian kembali mengenai faktor internal dan eksternal yang mempengaruhi kecenderungan penerimaan opini audit going concern. Rumusan masalah yang disajikan dalam penelitian ini adalah apakah ukuran perusahaan, pertumbuhan perusahaan, debt to equity ratio, kualitas audit, opini audit tahun sebelumnya berpengaruh terhadap kecenderungan penerimaan opini audit going concern.

\section{TINJAUAN TEORETIS}

\section{Teori Agensi (Agency Theory)}

Teori agensi menjelaskan bahwa dalam suatu perusahaan muncul suatu kontrak antara pemilik modal (principle) dan pengelola modal (agent). Kedua belah pihak akan memiliki fokusnya sendiri. Pemilik modal akan fokus pada keinginannya dalam going concern perusahaan sedangkan agent berfokus pada kesejahteraanya dalam pengelolaan perusahaan. Untuk mencapai keinginannya, pihak agent bisa saja melakukan halhal yang merugikan perusahaannya seperti melakukan salah saji maupun kecurangan. Hal ini karena adanya moral hazard dalam diri agent. Perbedaan kepentingan ini 
membuat adanya suatu jurang antara principle dan agent yang harus dijembatani oleh kehadiran pihak ketiga yang bersifat independen agar laporan keuangan yang dibuat oleh pihak agent dapat dipercaya oleh principle maupun stakeholder yang lainnya. Dalam menjalankan perikatan audit atas laporan keuangan, auditor bertanggungjawab dalam pemberian opini audit yang sesuai dengan kenyataannya. Selain dari pemberian audit atas laporan keuangan tahun buku yang mereka audit, auditor juga berkewajiban untuk menilai keberlangsungan hidup perusahaan. Hal ini karena banyak pihak yang berkepentingan dengan kondisi perusahaan untuk masa depan, contohnya saja adalah pihak bank dalam pemberian kredit untuk jangka panjang.

\section{Teori Sinyal (signaling theory)}

Teori sinyal yaitu menyampaikan suatu informasi kepada pengguna informasi yang menggambarkan kondisi perusahaan. Pengguna informasi yang terdiri dari investor, calon investor, kreditor akan merespon atas informasi yang diterima dari perusahaan sebagai bentuk sinyal yang diberikan oleh perusahaan terkait kondisi perusahaan. Perusahaan yang berada dalam kondisi baik akan menyampaikan informasi ke pengguna informasi dengan harapan mendapatkan tanggapan yang baik dari pengguna laporan keuangan atas informasi yang disampaikan.

Teori sinyal memiliki tujuan agar asimetri informasi antara manajemen perusahaan dengan pemegang saham dapat diminimalkan karena manajemen perusahaan biasanya memiliki lebih banyak informasi terkait perusahaan dibandingkan dengan pemegang saham. Hal ini tentunya sangat berbahaya terkait pengambilan keputusan oleh pemegang saham. Oleh karen itu diperlukan audit terhadap laporan keuangan perusahaan sehingga laporan keuangan yang disampaikan akan memberikan informasi yang valid sesuai dengan kondisi perusahaan sebenarnya.

\section{Opini Audit Going Concern}

Dalam mengaudit laporan keuangan, auditor akan menilai kewajaran penyajian laporan keuangan, apakah mengandung salah saji atau tidak. Selain itu, auditor juga wajib menilai kemampuan perusahaan untuk bertahan hidup. Opini ini dinamakan dengan opini audit going concern yaitu opini yang dikeluarkan auditor berdasarkan evaluasi dan judgmentnya terkait adanya kesangsian auditor tentang kemampuan perusahaan untuk mempertahankan kelangsungan hidupnya (Ikatan Akuntan Indonesia, 2017). Jenis laporan audit ini yaitu laporan audit dengan modifikasi mengenai going concern perusahaan memberikan suatu indikasi bahwa menurut judgment auditor terdapat risiko bahwa auditee tidak dapat mempertahankan bisnisnya. Jika dilihat dari kacamata auditor, judgment tersebut telah melewati beberapa analisis diantaranya adalah judgment terkait hasil operasi, kondisi perekonomian yang mempengaruhi perusahaan, kemampuan entitas dalam membayar utang, dan likuiditas periode mendatang.

Going concern perusahaan dipakai sebagai asumsi dalam melaporkan laporan keuangan sepanjang tidak terbukti adanya informasi yang menunjukkan contrary information, yaitu informasi yang dianggap berlawanan dengan asumsi kelangsungan hidup satuan usaha, terkait dengan ketidakmampuan satuan usaha dalam memenuhi kewajiban pada saat jatuh tempo dengan tanpa melakukan penjualan sebagian besar aktiva kepada pihak luar melalui bisnis biasa, restrukturisasi utang, perbaikan operasi yang dipaksakan dari luar dan kegiatan serupa yang lain (Ikatan Akuntan Indonesia, 2017).

Secara umum, beberapa kondisi dan peristiwa yang menyebabkan auditor mempertimbangkan secara keseluruhan kelangsungan hidup perusahaan dalam waktu yang pantas adalah sebagai berikut (Ikatan Akuntan Indonesia, 2017)

1) Adanya kondisi dengan trend yang mengalami penurunan, sebagai contoh kerugian operasi yang berulang-ulang 
terjadi, kurangnya modal kerja perusahaan untuk digunakan dalam operasionalnya, arus kas megalami defisit atau negatif dari kegiatan usaha, ratio keuangan penting perusahaan nilainya tidak sehat.

2) Petunjuk lain yang menggambarkan adanya kemungkinan perusahaan mengalami financial distress, sebagai contoh perusahaan mengalami kegagalan dalam memenuhi kewajiban utangnya atau perjanjian serupa baik dalam jangka pendek maupun dalam jangka panjang, penunggakan pembayaran dividen, penolakan oleh pemasok dalam kaitannya dengan pengajuan permintaan pembelian kredit, perusahaan melakukan restrukturisasi kredit, kebutuhan untuk mencari sumber atau metode pendanaan baru atau melakukan penjualan sebagian besar aktivanya.

3) Perusahaan mengalami risiko perusahaan (intern perusahaan), sebagai contoh pemogokan buruh atau adanya konflik terkait dengan hubungan perburuhan yang lain, ketergantungan besar atas kesuksesan pada suatu projek, adanya komitmen jangka panjang yang sebenarnya tidak ekonomis, kebutuhan untuk mencari sumber atau metode pendanaan baru.

4) Perusahaan mengalami risiko yang berasal dari pihak eksternal, sebagai contoh adanya pengaduan dan gugatan dari pihak pengadilan, adanya aturan atau undang-undang baru, atau masalahmasalah lain yang kemungkinan membahayakan kemampuan perusahaan untuk bertahan hidup, Hilangnya franchise, lisensi atau paten perusahaan, hilangnya pelanggan atau pemasok kunci perusahaan, mengalami kerugian yang diakibatkan oleh adanya bencana besar seperti gempa bumi, banjir, kekeringan, dimana ancaman tersebut dari awal tidak diasuransikan oleh pihak perusahaan ataupun diasuransikan namun dengan pertanggungan yang tidak mencukupi biaya yang harus dikeluarkan oleh perusahaan.

\section{Opini Audit}

Laporan keuangan hasil audit merupakan media yang dipakai oleh auditor dalam melakukan komunikasi dengan lingkungannya (stakeholdernya). Informasi utama dalam laporan auditor independen adalah opini audit. Melalui beberapa tahapan dalam melakukan audit, dan melalui judgment auditor maka kesimpulan auditor terkait dengan suatu laporan keuangan dituangkan dalam opini audit. Laporan audit merupakan langkah terakhir dari seluruh proses audit yang harus dilakukan oleh auditor. Dengan demikian, seorang auditor dalam mengeluarkan opini audit harus sudah didasarkan pada keyakinan profesionalnya sesuai dengan kode etik akuntan publik.

Tanggung jawab auditor dalam perikatan audit atas laporan keuangan (general audit) adalah pada opini yang mereka berikan. Opini yang diberikan akan bergantung pada beberapa hal diantaranya adalah materialitas salah saji pada laporan keuangan, pembatasan yang dilakukan oleh manajemen, kesesuaian dengan SAK, serta independensi dari auditor. Auditor akan memberikan opini dari wajar tanpa pengecualian yang merupakan opini audit bentuk baku hingga opini diluar bentuk baku tersebut.

Menurut Ikatan Akuntan Indonesia (2017) dilakukannya audit atas laporan keuangan oleh auditor ekstern adalah untuk menyatakan pendapat tentang kewajaran laporan keuangan, yaitu posisi keuangan, hasil usaha, perubahan ekuitas, dan arus kas sesuai dengan prinsip akuntansi yang berlaku umum (PABU) di Indonesia. Laporan auditor tersebut merupakan sarana bagi auditor untuk menyatakan pendapatnya dalam paragrap opini.

Auditor dapat memilih satu dari beberapa tipe opini yang akan dinyatakan atas laporan keuangan hasil audit. Tipe pendapat tersebut adalah 1) pendapat wajar tanpa pengecualian (unqualified opinion), 2) pendapat wajar tanpa pengecualian dengan bahasa penjelas (unqualified opinion with 
explanatory language), 3) pendapat wajar dengan pengecualian (qualified opinion), 4) pendapat tidak wajar (adverse opinion) dan 5) pernyataan tidak memberikan pendapat (disclaimer of opinion) (Jusup, 2014).

1) Pendapat Wajar Tanpa Pengecualian (Unqualified Opinion). Ini menandakan bahwa, judgment auditor menyimpulkan bahwa laporan keuangan klien disajikan secara wajar dalam semua hal yang yang bersifat material sesuai dengan PABU di Indonesia. Kondisi yang terkait dengan dikeluarkannya opini ini adalah 1). laporan keuangan lengkap berisi laporan neraca, laporan laba-rugi, laporan perubahan ekuitas, dan laporan arus kas. 2) Dalam pelaksanaan perikatan, auditor memenuhi kode etik terkait dengan diri auditor seperti independen, objektif dan integritas. 3) auditor telah memperoleh bukti kompeten yang cukup dan melakukan pengujianpengujian saat melaksanakan pekerjaan lapangan untuk memberikan opini atas kewajaran laporan keuangan. 4) Laporan keuangan hasil audit wajib disajikan dengan menggunakan prinsip akuntansi berterima umum di Indonesia. 5) Tidak adanya suatu kondisi atau keadaan yang mengharuskan auditor untuk memberikan tambahan paragraf penjelas atau modifikasi dalam laporan auditan.

2) Pendapat Wajar Tanpa Pengecualian dengan Bahasa Penjelas (Unqualified Opinion with Explanatory Language). Dalam situasi tertentu, auditor akan menambahkan suatu paragraf untuk menjelaskan terkait kondisi perusahaan dalam laporan auditan, meskipun sebenarnya hal tersebut tidak mempengaruhi pendapat wajar tanpa pengecualian atas laporan keuangan auditan. Paragraf penjelas tersebut akan dicantumkan pada paragraph setelah paragraf pendapat. Suatu keadaan atau kondisi yang menjadi penyebab utama ditambahkannya suatu paragraf penjelas atau modifikasi dari laporan audit bentuk baku adalah: 1) adanya ketidak konsistenan penerapan PABU dalam laporan keuangan klien, 2) Keraguan besar tentang kelangsungan hidup entitas, 3 ) adanya suatu penyimpangan dari prinsip akuntansi yang dikeluarkan oleh Dewan Standar Akuntansi Keuangan, 4) adaya suatu penekanan atas suatu hal, 5) Laporan auditan yang yang sebagian laporan keuangannya diaudit oleh auditor lain.

3) Pendapat Wajar dengan Pengecualian (Qualified Opinion). Pendapat wajar dengan pengecualian diberikan apabila auditee menyajikan secara wajar laporan keuangannya, dalam semua hal yang dianggap material sesuai dengan PABU di Indonesia, namun akan diberikan paragraph tambahan terkait dengan halhal yang dikecualikan. Pendapat wajar dengan pengecualian dinyatakan dalam keadaan 1) auditor menemukan kondisi dimana tidak adanya bukti kompeten yang cukup untuk mendukung laporan keuangan atau adanya pembatasan terhadap lingkup audit, 2) Auditor yakin bahwa laporan keuangan berisi penyimpangan dari PABU di Indonesia, yang berdampak material terhadap laporan keuangan, dan auditor berkesimpulan untuk tidak memberikan opini tidak wajar tidak wajar.

4) Pendapat Tidak Wajar (Adverse Opinion). Opini tidak wajar ini diberikan oleh auditor apabila laporan keuangan auditee tidak disajikan secara wajar laporan keuangan sesuai dengan PABU dalam hal yang material

5) Tidak Memberikan Pendapat (Disclaimer of Opinion). Auditor akan memberikan opini ini jika auditor tidak mampu melaksanakan audit dengan leluasa akibat adanya pembatasan lingkup audit oleh klien atau dalam kondisi dimana auditor bersifat tidak independen.

\section{Opini Audit Tahun Sebelumnya}

Sebelum memulai mengaudit laporan keuangan klien (baik itu klien baru maupun 
klien lama) maka auditor akan melakukan pemahaman terkait bisnis kliennya. Auditor akan mempelajari kertas kerja tahun lalu dan temuan-temuan audit yang tercermin dalam opini yang diberikan oleh auditor sebelumnya. Opini periode sebelumnya akan menjadi pedoman oleh auditor dalam pekerjaan lapangannya dan dalam pemberian opini untuk periode audit, apakah kembali akan memberikan opini audit going concern atau tidak. Mereka harus melihat perencanaan perusahaan dalam menanggulangi ketidak mampuannya dalam bertahan hidup. Kemungkinan besarnya adalah jika perusahaan periode lalu mendapatkan opini going concern maka kemungkinan besar perusahaan akan kembali memperoleh opini audit going concern ini.

Wati et al. (2017) membuktikan bahwa auditor tidak akan memberikan opini audit going concern jika perusahaan mampu menunjukkan kenaikan dari segi keuangan, jika tidak maka auditor akan tetap memberikan opini going concern.

\section{Ukuran Perusahaan}

Ukuran perusahaan dapat diukur dengan besar kecilnya asset perusahaan, penjualan, nilai pasar, dan kemudahan memperoleh dana dari pasar modal dimana dari ukuran tersebut mampu mengukur besar kecilnya perusahaan. Semakin besar asset, penjualan, nilai pasar dan kemampuan perusahaan memperoleh dana dari pasar modal maka perusahaan dapat dikategorikan sebagai perusahaan besar, dan sebaliknya.

\section{Kualitas Audit}

Kemampuan auditor dalam menemukan dan melaporkan pelanggaran yang ada di laporan keuangan disebut dengan kualitas audit (Dewana, 2015). Tujuan dari audit atas laporan keuangan adalah guna menjembatani manfaat yang ingin diperoleh oleh stakeholder dalam pengambilan keputusan. Laporan keuangan yang menyesatkan akan membuat keputusan yang diambil oleh stakeholder juga menyesatkan. Sehingga laporan hasil audit oleh KAP haruslah berkualitas. Auditor berskala internasional akan lebih menjaga citranya dibandingkan dengan auditor lain yang bukan berskala internasional (Kurnia dan Mella, 2018). KAP besar juga lebih mampu menghadapi risiko pengadilan akibat penanganan kliennya. Hal lainnya adalah KAP besar tidak memiliki ketergantungan yang besar dengan klien sehingga mereka akan melaporkan opini audit going concern kepada klien yang memang diragukan kelangsungan hidupnya tanpa ketakutan untuk kehilangan klien.

\section{Debt to Equity Ratio}

Rasio leverage (Debt to equity ratio) merupakan rasio untuk menggambarkan kondisi keuangan perusahaan yang dilihat dari segi proporsi utang yang dimiliki perusahaan dengan total modal perusahaan. Semakin tinggi rasio ini memiliki arti bahwa semakin besar utang yang dgunakan oleh perusahaan untuk menjalankan operasionalnya. Nilai rasio ini yang semakin besar menandakan semakin tingginya biaya yang harus dikeluarkan perusahaan untuk membayar biaya utangnya sehingga risiko perusahaan untuk default akan semakin tinggi yaitu risiko dimana perusahaan tidak mampu untuk membayar utangnya baik dalam jangka pendek maupun jangka panjang.

\section{Pertumbuhan Perusahaan}

Pertumbuhan perusahaan merupakan indikasi suatu perusahaan mengalami peningkatan dalam operasionalnya. Pertumbuhan perusahaan dapat dijadikan acuan suatu perusahaan bisa bertahan atau tidak untuk periode berikutnya. Dalam partumbuhan perusahaan menggambarkan kondisi perusahaan yang berkembang baik dari sisi asset maupun dari sisi pertumbuhan penjualan.

\section{Kerangka Berpikir}

Gambar 1 adalah gambar kerangka berpikir penelitian ini: 


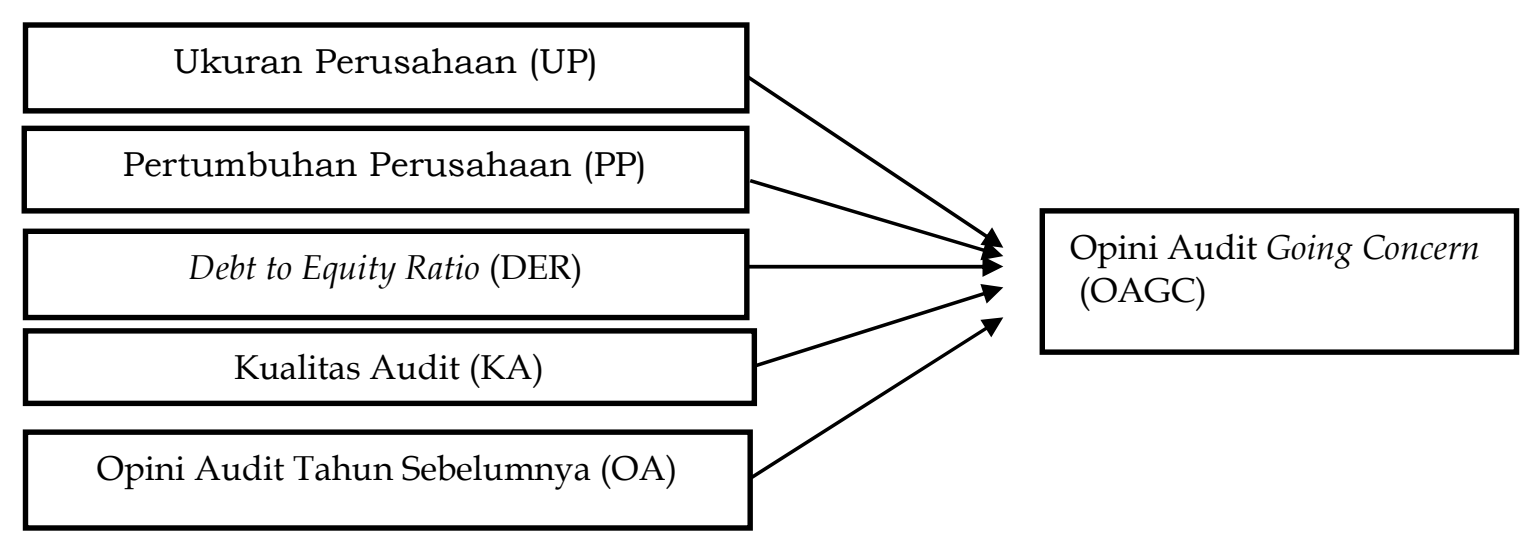

\section{Gambar 1 \\ Kerangka Berpikir}

\section{Rumusan Hipotesis}

Perusahaan yang memiliki asset yang besar mencerminkan perusahaan besar. Dengan memiliki asset yang besar, maka peluang untuk mendapatkan manfaat ekonomis berupa keuntungan akan semakin besar dengan memanfaatkan asset yang dimiliki. Dengan kondisi demikian tingkat penjualan perusahaan yang berada dalam kategori perusahaan besar akan cenderung stabil sehingga laba yang diperoleh juga cenderung stabil dengan asumsi kondisi ekonomi dan pasar berada dalam kondisi normal, sehingga peluang auditor untuk memberikan opini going concern akan semakin rendah. Begitu juga sebaiknya, jika perusahaan memiliki asset yang kecil yang dimanfaatkan untuk memperoleh keuntungan, maka peluang untuk memperoleh pendapatan akan cenderung tidak stabil dan rendah. Justru hal ini yang sangat rentan bagi perusahaan sehingga berpotensi mendapatkan opini going concern. Selain itu, perusahaan besar juga memiliki akses yang lebih besar pula dalam mencari dana di pasar modal, sehingga hal ini mampu menyangga keuangan perusahaan. Perusahaan besar akan memiliki struktur pengendalian intern yang lebih optimal dibandingkan dengan perusahaan yang lebih kecil. Dengan struktur pengendalian intern yang lebih tinggi akan menekan salah saji maupun kecurangan yang terjadi di perusahaan. Dengan rendahnya salah saji maupun kecurangan yang terjadi maka memudahkan perusahaan untuk mencapai tujuan organisasi sehingga auditor tidak akan memberikan opini audit going concern. Berdasarkan hasil penelitian Putri et al. (2019); Kusumaningrum dan Zulaikha, (2019), menunjukkan bahwa perusahaan yang besar cenderung tidak mendapatkan opini audit going concern. Maka hipotesis yang disajikan adalah sebagai berikut:

$\mathrm{H}_{1}$ : Semakin besar ukuran perusahaan maka peluang diberikan opini audit going concern akan menurun.

Pertumbuhan perusahaan mencerminkan kondisi perusahaan yang mengalami peningkatan dari asset ataupun penjualan. Perusahaan yang mengalami peningkatan asset atau penjualan, maka perusahaan tersebut sedang berada dalam kondisi keuangan yang stabil dan cenderung meningkat. Perusahaan yang mengalami pertumbuhan maka penjualan akan cenderung mengalami peningkatan sehingga laba yang didapatkan juga cenderung mengalami peningkatan. Kondisi ini menunjukkan perusahaan berada dalam kondisi keuangan yang baik. Tentunya hal ini akan memberikan gambaran kondisi perusahaan yang mampu bertahan dalam menghadapi persaingan sehingga auditor akan tidak memberikan opini audit going concern. Penelitian $\mathrm{Al}^{\prime}$ adawiah et al. (2020); Pratiwi dan Lim (2018); Purba dan Nazir, (2019) bahwa faktor pertumbuhan perusahaan memiliki pengaruh negatif sig- 
nifykan terhadap opini audit going concern. Maka hipotesis yang disajikan adalah sebagai berikut:

$\mathrm{H}_{2}$ : Semakin meningkat pertumbuhan perusahaan maka akan berkurang kemungkinan mendapatkan opini audit going concern.

Debt to equity ratio melihat kewajiban perusahaan dibandingkan dengan ekuitasnya. Semakin besar persentase kewajiban perusahaan dibandingkan dengan ekuitas yang dimiliki, maka itu menggambarkan perusahaan akan mengalami permasalahan terkait kemampuan perusahaan didalam melunasi kewajibannya yang akan jatuh tempo. Perusahaan yang aktivitas pendanaannya lebih banyak didanai dengan hutang akan cenderung memiliki resiko kegagalan dalam melunasi kewajibannya lebih besar karena sebagian ekuitasnya akan dialokasikan ke pembayaran hutang perusahaan. Potensi ini yang pasti dilihat oleh auditor bahwa perusahaan memiliki resiko sehingga peluang diberikan pendapat going concern akan semakin besar. Perusahaan yang telah memiliki hutang tinggi juga memiliki peluang yang lebih kecil untuk memperoleh pendanaan Ketika memutuskan untuk meningkatkan pendanaan guna pengembangan usaha. Penelitian Kadirisman (2018); Kusumaningrum dan Zulaikha, (2019), menemukan bahwa rasio debt default berpengaruh positif signifikan terhadap penerimaan opini audit going concern.

$\mathrm{H}_{3}$ : Semakin besar Debt to equity ratio perusahaan akan meningkatkan kecenderungan penerimaan opini audit going concern.

Kualitas audit memegang peranan penting dalam hal pelaksanaan proses audit dan hasil audit yang berupa opini audit yang diberikan oleh auditor. Semakin baik kualitas audit yang dilakukan oleh auditor, maka scope audit, pemeriksaan bukti-bukti akan dilakukan dengan objektif, dimana auditor akan menjalankan setiap tahapan dalam audit dengan menjunjung tinggi integritas, kode etik dan profesionalisme. Dengan demikian, maka opini audit yang diberikan yang didasarkan atas objektifitas dan independensi akan memberikan informasi yang mencerminkan kondisi perusahaan yang sebenarnya. Semakin baik kualitas audit maka auditor akan menjalankan tahapan audit dengan sebaik-baiknya untuk mendeteksi kecurangan yang terjadi dalam perusahaan, sehingga kecurangan yang terjadi dalam perusahaan dapat ditemukan dan jika hal tersebut dapat mengancam keberlangsungan perusahaan, maka auditor akan memberikan opini audit going concern. KAP berafiliasi internasional diyakini memiliki kualitas audit yang jauh lebih tinggi karena KAP tersebut memiliki kuantitas dan kualitas auditor yang jauh lebih tinggi. Dengan pengalaman, pelatihan dan profesionalisme yang lebih tinggi maka akan memberikan kualitas audit yang tinggi. KAP tersebut juga memiliki klien yang banyak sehingga tidak akan ada ketakutan untuk kehilangan klien atau tidak mengalami ketergantungan dengan klien sehingga semakin mampu untuk memberikan opini audit going concern jika klien mengalami masalah keuangan.

Kurnia dan Mella (2018); Purba dan Nazir (2019) berhasil membuktikan bahwa kualitas auditor memiliki pengaruh positif yang signifikan terhadap opini audit going concern. Maka hipotesis keempat dalam penelitian ini adalah:

$\mathrm{H}_{4}$ : Semakin baik kualitas audit maka akan meningkatkan peluang penerimaan opini audit going concern.

Opini audit tahun sebelumnya bisa dijadikan salah satu indikator terkait kondisi perusahaan. Perusahaan yang mendapatkan opini audit going concern pada periode sebelumnya mengindikasikan ada masalah terhadap kemampuan perusahaan untuk bertahan dimasa akan datang. Kondisi itu akan diperhatikan oleh auditor dalam melaksanakan audit dan semakin hati-hati dalam menilai perusahaan dan memberikan opini. Semakin baik opini audit yang diberikan pada periode sebelumnya, maka peluang auditor memberikan opini audit going concern semakin menurun, begitu juga sebaliknya, jika periode sebelumnya perusa- 
haan menerima opini audit going concern, maka kecenderungan auditor akan memberikan opini audit going concern akan meningkat. Auditor wajib untuk memahami bisnis kliennya (baik itu klien baru maupun klien lama) dengan membaca kertas kerja periode lalu dan hasil audit auditor sebelumnya. Jika periode sebelumnya perusahaan disangsikan kelangsungan hidupnya maka auditor akan lebih berhati-hati dan mungkin akan tetap memberikan opini going concern apabila perusahaan belum mampu melaksanakan suatu rencana untuk mengatasi masalah keuangannya. Fahmi (2015); Nafiatin (2017) menemukan bukti bahwa opini audit tahun sebelumnya signifikan berpengaruh positif terhadap penerimaan opini audit going concern. Hipotesis yang disajikan adalah sebagai berikut:

$\mathrm{H}_{5}$ : Jika perusahaan mendapatkan opini audit going concern sebelumnya, maka kecenderungan perusahaan akan penerimaan opini audit going concern.

\section{METODE PENELITIAN}

Penelitian ini dilakukan pada perusahaan manufaktur yang terdaftar di Bursa Efek Indonesia periode 2016 sampai 2019. Fokus penelitian pada perusahaan manufaktur untuk menghindari adanya efek karena perbedaan jenis industri. Objek penelitian dalam penelitian ini adalah laporan keuangan tahunan pada perusahaan manufaktur yang terdaftar di Bursa Efek Indonesia periode 2016 sampai 2019.

\section{Opini Audit Going concern}

KAP selain bertanggungjawab untuk menilai kewajaran laporan keuangan yang sedang diaudit, juga bertanggungjawab untuk menilai kemampuan perusahaan untuk mempertahankan kelangsungan hidupnya. Jika auditor merasa kelangsungan hidup perusahaan terganggu maka akan menambahkan penjelasan terkait dengan kelangsungan hidup perusahaan. Variabel ini merupakan dummy variable dimana kode 1 diberikan jika auditor menyangsikan kebertahanan perusahaan dalam menjalankan perusahaan sedangkan kode 0 jika auditor tidak menyangsikannya.

\section{Ukuran Perusahaan}

Ukuran perusahaaan mencerminkan besar kecilnya perusahaan. Perusahaan besar akan memiliki total asset yang lebih besar dari perusahaan dengan ukuran lebih kecil. Hal ini karena dengan adanya aktiva ini akan menopang perusahaan untuk memiliki produktivitas yang lebih tinggi.

\section{Pertumbuhan Perusahaan}

Salah satu cermin dari adanya partumbuhan perusahaan adalah adanya meningkatnya penjualannya dengan membandingkannya penjualan periode sebelumnya.

\section{Debt to equity ratio}

Rasio ini merupakan rasio utama yang digunaka para analis untuk menilai posisi keuangan perusahaan. Rasio ini menggambarkan sejauh mana perusahaan mampu melunasi kewajibannya dengan membandingkan antara kewajiban dengan ekuitas perusahaan (Minerva et al., 2020).

\section{Kualitas Audit}

Kualitas audit berkaitan erat dengan reputasi auditor. Auditor yang berafiliasi dengan KAP big four cenderung memiliki kualitas audit yang lebih tinggi karena KAP tersebut telah diakui secara internasional, auditornya lebih berpengalaman, professionnal dan pelatihan yang jauh lebih banyak. Pengukuran variabel ini dengan nilai 1 kepada KAP yang berafiliasi dengan big four dan 0 jika tidak.

\section{Opini Audit Tahun Sebelumnya}

Opini audit ini merupakan opini yang diberikan oleh auditor untuk laporan keuangan tahun sebelumnya. Variabel ini merupakan variabel dummy dengan memberikan nilai 1 pada perusahaan yang mendapat opini going concern pada periode sebelumnya dan nilai 0 pada perusahaan yang tidak memperoleh opini going concern pada periode sebelumnya. 
Tabel 1

Proses Penentuan Sampel

\begin{tabular}{clc}
\hline \hline No. & \multicolumn{1}{c}{ Kriteria Sampel } & Jumlah \\
\hline 1. & Perusahaan manufaktur yang terdaftar di BEI periode 2016-2019 & 165 \\
2. & Perusahaan yang tidak menggunakan mata uang Rupiah & $(20)$ \\
3. & Data-data mengenai variabel penelitian yang diteliti tidak lengkap & $(77)$ \\
& Jumlah sampel akhir & 68 \\
& Jumlah pengamatan & $\mathbf{2 7 2}$ \\
\hline
\end{tabular}

Sumber: Data diolah

\section{Populasi dan Sampel}

Populasi penelitian ini adalah perusahaan manufaktur yang terdaftar di Bursa Efek Indonesia (BEI) periode 2016-2019. Populasi berjumlah 165 perusahaan. Metode penentuan sampel yang digunakan dalam penelitian ini adalah teknik purposive sampling yaitu teknik penentuan sampel dengan pertimbangan tertentu. Tabel 1 menunjukkan proses penentuan sampel dengan kriteria tertentu.

\section{Teknik Analisis}

Teknik analisis data yang dipergunakan dalam penelitian ini adalah regresi logistik. Teknik analisis ini digunakan karena menguji pengaruh variabel bebas ke variabel terikat dimana variabel terikat diukur menggunakan dummy.

\section{ANALISIS DAN PEMBAHASAN Uji Statistik Deskriptif}

Karakteristik data yang digambarkan pada hasil uji statistik deskriptif yang tercantum pada Tabel 2 yang menunjukkan nilai minimum, maksimum, rata-rata, dan standar deviasi.

Tabel 2

Statistik Deskriptif

\begin{tabular}{lcccrr}
\hline \hline & $\mathbf{N}$ & Min & Max & Mean & Std. \\
\hline Size & 272 & 22.69 & 36.21 & 28.50 & 1.89 \\
PP & 272 & .20 & .60 & .41 & .09 \\
DER & 272 & -7.23 & 123.15 & 1.95 & 8.94 \\
KA & 272 & .00 & 1.00 & .45 & .49 \\
OA & 272 & .00 & 1.00 & .02 & .15 \\
GC & 272 & .00 & 1.00 & .03 & .19 \\
\hline
\end{tabular}

Sumber : data diolah
Berdasarkan Tabel 2 yang merupakan statistik deskriptif dari data yang disajikan dapat dijelaskan sebagai berikut:

1 Ukuran perusahaan (size) memiliki mean sebesar 28,5095 dengan nilai terendah 22,69 dan tertinggi 36,21 dengan standar deviasi sebesar 1,89822 . Nilai mean sebesar 28,5095 mengindikasikan bahwa ratarata perusahaan yang dijadikan sampel termasuk kategori perusahaan dengan skala cukup besar. Nilai standar deviasi 1,89822 mengindikasikan bahwa variasi rata-rata ukuran perusahaan yang dijadikan sampel dalam penelitian ini memiliki variasi nilai yang kecil.

2 Pertumbuhan perusahaan (PP) memiliki mean sebesar 0,41 dengan standar deviasi sebesar 0,09. Nilai mean sebesar 0,41 maka dapat digambarkan bahwa sampel dalam penelitian ini didominasi oleh perusahaan yang mengalami partumbuhan dari sisi penjualannya. Nilai standar deviasi 0,09 mengindikasikan variasi rata-rata pertumbuhan perusahaan yang dijadikan sampel memiliki variasi nilai relatif kecil.

3 Debt to equity ratio (DER) memiliki mean sebesar sebesar 1,9546 dengan nilai terendah $-7,23$ dan tertinggi 3,15 dengan standar deviasi sebesar 8,94557. Nilai mean sebesar 1,9546 mengindikasikan bahwa perusahaan yang dijadikan sampel merupakan perusahaan yang memiliki rasio utang yang tergolong tinggi. Nilai standar deviasi sebesar 8,94557 mengindikasikan bahwa variasi rata-rata DER yang dijadikan sebagai sampel memiliki variasi nilai cukup besar. 
4 Kualitas audit (KA) memiliki mean sebesar 0,4559 yang lebih kecil dari 0,50 menunjukkan bahwa kualitas audit dengan kode 1, yakni KAP yang berafiliasi dengan Big four lebih sedikit muncul dari 204 perusahaan sampel. Nilai standar deviasi sebesar 0,49 mengindikasikan variasi rata-rata kualitas audit yang dijadikan sampel memiliki variasi nilai yang sangat kecil.

5 Opini audit tahun sebelumnya (OA) memiliki mean sebesar 0,0245 yang lebih kecil dari 0,50 menunjukkan bahwa opini audit tahun sebelumnya dengan kode 1 , yaitu yang menerima opini audit going concern lebih sedikit muncul atau degan kata lain sampel dalam penelitian ini didominasi oleh perusahaan yang tidak mengalami gangguan kelangsungan usahanya pada peiode sebelumnya.

6 Opini audit going concern (GC) memiliki nilai mean sebesar 0,03 yang lebih kecil dari 0,50 menunjukkan bahwa opini audit dengan kode 1, yakni opini audit going concern lebih sedikit muncul atau dengan kata lain sampel dalam penelitian ini didominasi oleh perusahaan yang tidak mengalami gangguan dalam kelangsungan usahanya.

\section{Analisis Regresi Logistik}

Teknik analisis yang dipergunakan dalam penelitian ini dengan menggunakan regresi logistik. Penggunaan analisis regresi logistik adalah karena variabel dependen bersifat dikotomi (tepat atau tidak tepat). Dalam melakukan analisis regresi logistik, dilakukan pengujian kelayakan model regre- si, menilai keseluruhan model, koefisien determinasi, pengujian hipotesis, matriks klasifikasi, pengujian multikoleniaritas dan menilai model regresi logistik yang terbentuk (Ghozali dan Ratmono, 2017).

\section{Menilai Kelayakan Model}

Penilaian kelayakan model dilakukan dengan melihat nilai hosmer and Lemeshow's test untuk mengetahui apakah model penelitian mampu memprediksi nilai observasinya.

\section{Tabel 3}

Hosmer and Lameshow's Test

\begin{tabular}{llll}
\hline \hline Step & Chi-square & df & Sig. \\
\hline 1 & 4.740 & 8 & .785 \\
\hline \multicolumn{2}{l}{ Sumber: Data diolah }
\end{tabular}

Nilai statistik Hosmer and Lemeshow's Goodness of Fit Test pada tabel 3 adalah 4,740 dengan probabilitas signifikansi 0,785 yang nilainya diatas 0,05 . Dengan demikian dapat disimpulkan bahwa model mampu memprediksi nilai observasinya atau dapat dikatakan model dapat diterima karena cocok dengan data observasinya.

\section{Menilai Keseluruhan Model (overall model} fit)

Berdasarkan Tabel 4 dan Tabel 5 dapat dilihat bahwa hasil -2 Log Likelihood (-2LL) pada awal Block Number $=0$ adalah 221,762 dan nilai -2 Log Likelihood (-2LL) pada akhir Block Number $=1$ adalah 195,922. Ini berarti bahwa terdapat penurunan nilai likelihood (2LL), jadi disimpulkan bahwa model regresi yang dihipotesiskan fit dengan data.

Tabel 4

Overall Model Fit Step 0

\begin{tabular}{lccc}
\hline \multicolumn{4}{c}{ Overall Model Fit Step 0 } \\
\hline Iteration & -2Log likelihood & Coefficients Constant \\
\hline Step 0 & 1 & 221.762 & -1.456 \\
& 2 & 216.414 & -1.802 \\
& 3 & 216.343 & -1.848 \\
& 4 & 216.343 & -1.849 \\
\hline
\end{tabular}


Tabel 5

Overall Model Fit Step 1

\begin{tabular}{|c|c|c|c|}
\hline \multicolumn{4}{|c|}{ Model Summary } \\
\hline Step & -2 Log likelihood & Cox E Snell R Square & Nagelkerke R Square \\
\hline 1 & $195.922^{\mathrm{a}}$ & .072 & .132 \\
\hline
\end{tabular}

Koefisien Determinasi ( $\left.\mathbf{R}^{2}\right)$

Pengukuran koefisien Determinasi dalam penelitian ini diukur dengan menggunakan nilai nagelkerke $R$ square. Nilai

koefisien determinasi ditampilkan dalam Tabel 6.

Berdasarkan Tabel 6 dapat dilihat bahwa hasil Nagelkerke $R$ Square adalah sebesar 0,132 atau $13,2 \%$ menunjukkan variabel dari opini audit going concern mampu dijelaskan oleh variabel ukuran perusahaan, partumbuhan perusahaan, debt to equity ratio, kualitas audit dan opini audit tahun sebelumnya dan sisanya 86,8\% dipengaruhi oleh variabel-variabel lain diluar model penelitian.

\section{Tabel 6}

Koefisien Determinasi

$\frac{\text { Nagelkerke } R \text { Square }}{.132}$
Sumber: Data diolah

\section{Matriks Klasifikasi}

Menilai kemampuan model secara keseluruhan dalam memprediksi, maka digunakan nilai overall percentage dalam matriks klasifikasi yang ditampilkan dalam Tabel 7.

Berdasarkan Tabel 7 tersebut menunjukkan dari 272 amatan yang tidak memperoleh opini going concern (kode 0) sebanyak 272 amatan atau 100,0\% secara tepat dapat diprediksi oleh model regresi logistik, dan tidak ada amatan yang tidak dapat diprediksi, Dari keseluruhan model dapat memprediksi sebesar $86,4 \%$.
Tabel 7

Matriks Klasifikasi

\begin{tabular}{cccccc}
\hline \hline \multicolumn{5}{c}{ Classification Table } \\
\hline & & \multicolumn{3}{c}{ Predicted $^{\mathbf{a}}$} \\
\cline { 3 - 6 } & & \multicolumn{2}{c}{ GC } & Percentage \\
\cline { 3 - 5 } & Observed & $\mathbf{. 0 0}$ & $\mathbf{1 . 0 0}$ & Correct \\
\hline Step & GC & .00 & 235 & 0 & 100.0 \\
1 & 1.00 & 37 & 0 & .0 \\
& Overall & & & 86.4 \\
\hline
\end{tabular}

Sumber: Data diolah

\section{Omnibus test}

Omnibus test menunjukkan pengujuan secara simultan yaitu apakah variabel independen secara bersama-sama berpengaruh terhadap variabel dependen. Nilai Omnibus Test ditunjukkan pada Tabel 8 berikut ini.

Tabel 8

Omnibus Test

\begin{tabular}{ccccc}
\hline \hline \multicolumn{5}{c}{ Omnibus Tests of Model Coefficients } \\
\hline Step 1 & Chi-square & df & Sig. \\
& Block & 20.422 & 5 & .001 \\
& 20.422 & 5 & .001 \\
Model & 20.422 & 5 & .001 \\
\hline
\end{tabular}

Sumber: Data diolah

Nilai signifikansi Omnibus test of model coefficient sebesar 0,001 $<0,05$ menunjukkan adanya minimal ada 1 (satu) variabel independen yang berpengaruh terhadap opini audit going concern.

\section{Multikolinieritas}

Pengujian multikolinieritas dilakukan untuk mengetahui apakah sesama variabel bebas terdapat hubungan atau tidak. Model yang baik adalah sesama variabel bebas tidak terdapat hubungan. Nilai multikolinieritas dapat dilihat pada Tabel 9. 
Tabel 9

Matrik Korelasi

\begin{tabular}{llcccccc}
\hline \hline \multicolumn{7}{c}{ Correlation Matrix } \\
\hline Step 1 & Constant & Size & PP & DER & KA & OA \\
& Size & 1.000 & -.579 & -.373 & -.487 & .557 & .202 \\
& -.579 & 1.000 & -.243 & -.194 & .130 & -.271 \\
& PP & -.373 & -.243 & 1.000 & .064 & -.008 & -.010 \\
& DER & -.487 & -.194 & .064 & 1.000 & .636 & -.078 \\
& KA & -.557 & .130 & -.008 & .636 & 1.000 & -.086 \\
& OA & .202 & -.271 & -.010 & -.078 & -.086 & 1.000 \\
\hline
\end{tabular}

Sumber: Data diolah

Tabel 10

Hasil Pengujian

\begin{tabular}{cccccccc}
\hline \hline \multicolumn{7}{c}{ Variables in the Equation } \\
\hline Step 1a & Size & -5.390 & 2.284 & 5.570 & 1 & .018 & .005 \\
& PP & -4.268 & 2.182 & 3.828 & 1 & .050 & 71.389 \\
& DER & -2.769 & 1.610 & 2.958 & 1 & .085 & .063 \\
KA & 5.416 & 2.161 & 6.283 & 1 & .012 & .004 \\
& OA & .919 & .412 & 4.984 & 1 & .026 & 2.507 \\
& Constant & 1.786 & 1.754 & 1.036 & 1 & .309 & 5.965 \\
\hline
\end{tabular}

Sumber: Data diolah

Berdasarkan Tabel 9 dapat dilihat bahwa hasil Correlation Matrix antara variabel lebih kecil dari 0,8 . Jadi dapat disimpulkan bahwa tidak terdapat gejala multikolinearitas antara variabel bebas.

\section{Model Regresi Logistik}

Hasil analisis dengan menggunakan regresi logistik dapat dilihat pada Tabel 10. Berdasarkan Tabel 10 didapatkan penjelasan sebagai berikut:

$1 a=$ Nilai konstanta sebesar 1,786 artinya, bila ukuran perusahaan (Size), partumbuhan perusahaan (PP), Debt to equity ratio (DER), kualitas auditor (KA), dan opini audit tahun sebelumnya (OAS) sama dengan nol, maka pemberian opini audit going concern mengalami peningkatan sebesar 1,786 persen.

2 Koefisien regresi ukuran perusahaan sebesar $-5,390$ dengan nilai signifikansi
$0,018<0,05$ yang berarti bahwa jika ukuran perusahaan mengalami peningkatan sebesar $1 \%$ maka pemberian opini audit going concern mengalami penurunan sebesar 5,390\% dengan asumsi variabel lain konstan.

3 Koefisien regresi pertumbuhan perusahaan sebesar $-4,268$ dengan nilai signifykasi 0,050 $\leq 0,05$ yang berarti bahwa jika terjadi peningkatan pertumbuhan perusahaan sebesar $1 \%$, maka pemberian opini audit going concern mengalami penurunan sebesar 4,268\% dengan asumsi variabel lain konstan.

4 Koefisien regresi debt to equity ratio sebesar -2,769 dengan nilai signifikansi $0,058>0,05$ sehingga debt to equity ratio tidak berpengaruh terhadap penerimaan opini audit going concern

5 Koefisien regresi kualitas audit sebesar 5,416 dengan nilai signifikansi 0,012 < 
0,05 yang berarti bahwa jika terdapat peningkatan kualitas audit sebesar 1 satuan maka pemberian opini audit going concern akan meningkat sebesar 5,416\% dengan asumsi variabel lain konstan.

6 Koefisien regresi opini audit tahun sebelumnya sebesar 0,919 dengan nilai siginifikansi sebesar 0,026 < 0,05 sehingga jika terjadi peningkatan pemberian opini audit tahun sebelumnya sebesar satu satuan maka pemberian opini audit going concern akan meningkat sebesar $0,919 \%$ dengan asumsi variabel lain konstan.

\section{Pengujian Hipotesis}

Hasil pengujian regresi dapat ditunjukkan sebagai berikut:

Hipotesis 1 dalam penelitian ini adalah ukuran perusahaan berpengaruh negatif terhadap kecenderungan penerimaan opini audit going concern. Berdasarkan Tabel 10 nilai signifikansi sebesar 0,018 $<0,05$ dengan nilai koefisien sebesar -5,390. Hal ini mengindikasikan bahwa ukuran perusahaan berpengaruh negatif terhadap penerimaan opini audit going concern yang artinya $\mathrm{H}_{1}$ diterima. Semakin besar ukuran perusahaan menunjukkan semakin besar asset yang dimiliki oleh perusahaan yang dipergunakan untuk memperoleh pendapatan sehingga potensi mendapatkan keuntungan juga semakin meningkat. Keuntungan meningkat maka keberlangsungan hidup perusahaan masih bisa dijaga dengan baik sehingga peluang auditor memberikan opini audit going concern semakin menurun. Kelangsungan hidup usaha biasanya dikaitkan dengan kemampuan perusahaan untuk meningkatkan profitabilitas. Hasil penelitian ini mendukung hasil penelitian ( $\mathrm{Al}^{\prime}$ adawiah et al., 2020; Andyny, 2017; Effendi, 2019; Wati et al., 2017). Opini going concern akan diberikan kepada perusahaan yang tidak mampu mengelola perusahaannya dengan baik, dari aspek pelanggan, supplier atau dari manajerial. Perusahaan besar cenderung memiliki tata kelola yang semakin baik, pengendalian internal yang semakin baik sehingga kecil kemungkinan auditor memberikan opini audit going concern. Dari aspek pelanggan misalnya, semakin besar ukuran perusahaan maka pelanggan akan perusahaan akan mampu menumbuhkan loyalitas pelanggan agar menjadi pelanggan jangka panjang.

Hipotesis 2 dalam penelitian ini adalah pertumbuhan perusahaan berpengaruh negatif terhadap kecenderungan penerimaan opini audit going concern. Berdasarkan Tabel 10 nilai signifikansi sebesar 0,05 $\leq 0,05$ dengan nilai koefisien sebesar $-4,268$. Hal ini menunjukkan bahwa pertumbuhan perusahaan berpengaruh negatif terhadap penerimaan opini audit going concern yang artinya $\mathrm{H}_{2}$ diterima. Pertumbuhan perusahaan diproksikan dengan sales growth dimana jika pertumbuhan penjualan lebih besar dan diikuti dengan efisiensi beban operasional maka laba yang didapat tentunya akan semakin meningkat, sehingga meningkatnya laba akan menjamin keberlangsungan perusahaan dimasa depan sehingga peluang mendapatkan opini audit going concern semakin menurun. Hasil penelitian ini mendukung hasil penelitian (Al Fath dan Sugito, 2020; Putra et al., 2017; Putri, 2018; Rahmawati et al., 2018; Supriyadi, 2018), yang menyatakan pertumbuhan perusahaan mampu mengurangi kecenderungan penerimaan opini audit going concern.

Hipotesis 3 dalam penelitian ini adalah debt to equity ratio berpengaruh positif terhadap kecenderungan penerimaan opini audit going concern. Berdasarkan Tabel 10 nilai signifikansi sebesar $0,085>0,05$. Hal ini menunjukkan tidak adanya pengaruh debt to equity ratio terhadap penerimaan opini audit going concern yang artinya $\mathrm{H}_{3}$ ditolak. Kondisi ini menunjukkan bahwa rasio utang perusahaan tidak mutlak menentukan perusahaan mendapatkan atau tidak opini audit going concern. Pendanaan dari pihak ketiga tinggi, selama mampu dimanfaatkan oleh perusahaan untuk memaksimalkan potensinya memperoleh keuntungan, maka akan mampu meningkatkan keuntungan perusahaan, tetapi sebaliknya pendanaan dari pihak ketiga tinggi dan perusahaan tidak 
mampu memaksimalkan untuk mendanai investasinya dalam rangka memperoleh keuntungan, maka beban perusahaan akan tinggi dan keberlangsungan perusahaan bisa terganggu. Walaupun utang perusahaan tinggi belum tentu risiko dalam perusahaan juga tinggi, bahkan kemungkinan perusahaan untuk berkembang akan jauh lebih tinggi dengan adanya suntikan dana dari pihak ketiga jika dana ini dikelola dengan baik. Kesimpulannya rasio pinjaman tinggi ataupun rendah tapi yang terpenting adalah bagaimana mengelola dan memanfaatkan peluang dalam memperoleh keuntungan yang didanai oleh pendanaan pihak ketiga. Hasil penelitian ini mendukung hasil penelitian (Purba dan Nazir, 2019; Putri, 2018; Rahman dan Ahmad, 2018) yang menyatakan debt to equity ratio tidak berpengaruh terhadap kecenderungan penerimaan opini audit going concern.

Hipotesis 4 dalam penelitian ini adalah kualitas audit berpengaruh positif terhadap kecenderungan penerimaan opini audit going concern. Berdasarkan Tabel 10 nilai signifikansi sebesar 0,012 < 0,05 dengan nilai koefisien sebesar 5,416. Hal ini menunjukkan bahwa semakin tinggi kualitas audit, maka mampu menemukan berbagai jenis kecurangan yang terjadi dalam perusahaan sehingga semakin besar peluang mendapatkan opini audit going concern yang artinya $\mathrm{H}_{4}$ diterima. Pelaksanaan audit atas laporan keuangan yang dilakukan auditor harus tetap menjunjung tinggi kode etik sehingga audit bisa dilakukan secara independen. Hal ini bisa menunjukkan bahwa semakin baik kualitas audit yang dilakukan yang dicerminkan dengan audit dilakukan oleh KAP big four maka auditor mampu mendeteksi segala jenis penyimpangan atau kecurangan yang terjadi di dalam perusahaan. KAP big four dalam proses audit susah untuk diajak bekerjasama atau kompromi dalam hal memberikan opini audit going concern sehingga jika terjadi potensi kecurangan dan berpengaruh pada keberlangsungan perusahaan, maka auditor akan memberikan opini audit going concern. Semakin baik kualitas audit maka auditor bekerja sesuai dengan kode etik, seperti independen, professional, objektif dan bekerja dengan cermat dan seksama (skeptis) maka auditor mampu memberikan judgment audit dengan baik sehingga jika perusahaan mengalami gangguan terkait keberlangsungan hidupnya maka ia mampu mencermatinya dan menuangkannya dalam laporan auditan. Hasil penelitian ini mendukung hasil penelitian (Aiisiah, 2012; Andyny, 2017; Effendi, 2019) yang menyatakan kualitas audit berpengaruh positif terhadap kecenderungan penerimaan opini audit going concern.

Hipotesis 5 dalam penelitian ini adalah opini audit tahun sebelumnya berpengaruh positif terhadap kecenderungan penerimaan opini audit going concern. Berdasarkan Tabel 10 nilai signifikansi sebesar 0,026 $<0,05$ dengan nilai koefisien sebesar 0,919 . Hal ini menunjukkan bahwa jika perusahaan mendapatkan opini going concern pada tahun sebelumnya maka kemungkinan besar perusahaan mendapatkan opini audit going concern. Hal ini berarti hipotesis $\mathrm{H}_{5}$ diterima. Kondisi ini menunjukkan bahwa opini audit tahun sebelumnya dijadikan pertimbangan bagi auditor untuk mengeluarkan kembali opini audit going concern pada tahun berikutnya. Auditor dalam melakukan audit akan melihat opini audit yang diberikan periode sebelumnya sebagai pertimbangan didalam memberikan opini audit going concern. Hasil penelitian ini mendukung hasil penelitian (Pratiwi dan Lim, 2018; Rahmawati et al., 2018; Putri et al., 2019) yang menyatakan opini audit tahun sebelumnya dijadikan pertimbangan dalam memberikan opini audit periode sekarang.

\section{SIMPULAN DAN SARAN Simpulan}

Berdasarkan hasil pembahasan penelitian, maka dapat disimpulkan hal-hal sebagai berikut:

1. Auditor dalam menentukan opini audit going concern yang diberikan didasarkan pada besar kecilnya perusahaan. Kelangsungan hidup usaha biasanya dikaitkan 
dengan kemampuan perusahaan untuk meningkatkan profitabilitas. Semakin besar ukuran suatu perusahaan maka semakin besar asset yang dimiliki yang dipergunakan untuk memperoleh pendapatan sehingga peluang mendapatkan keuntungan semakin meningkat. Kondisi seperti ini akan menurunkan potensi perusahaan mendapatkan opini audit going concern.

2. Pertumbuhan perusahaan yang diproksikan dengan sales growth dimana jika pertumbuhan penjualan besar maka mengindikasikan perusahaan berada dalam kondisi yang baik untuk mampu mempertahankan keberlangsungan di masa depan. Peningkatan penjualan dan dengan tetap menjaga efisiensi perusahaan, maka keuntungan yang diperoleh semakin meningkat sehingga potensi perusahaan untuk mendapatkan opini audit going concern semakin kecil.

3. Debt to equity ratio tidak mampu mempengaruhi pemberian opini audit going concern. Kondisi ini menunjukkan bahwa rasio utang perusahaan tidak mutlak menentukan perusahaan mendapatkan atau tidak opini audit going concern. Pendanaan dari pihak ketiga tinggi, selama mampu dimanfaatkan oleh perusahaan untuk memaksimalkan potensi untuk memperoleh keuntungan, maka akan mampu meningkatkan keuntungan perusahaan, tetapi sebaliknya pendanaan dari pihak ketiga tinggi dan perusahaan tidak mampu memaksimalkan untuk mendanai investasinya dalam rangka memperoleh keuntungan, maka beban perusahaan akan tinggi dan keberlangsungan perusahaan bisa terganggu. Kesimpulannya rasio pinjaman tinggi ataupun rendah tetapi yang terpenting adalah bagaimana mengelola dan memanfaatkan peluang dalam memperoleh keuntungan yang didanai oleh pendanaan pihak ketiga.

4. Kualitas audit mampu meningkatkan potensi pemberian opini audit going concern. Kenyataannya pelaksanaan audit atas laporan keuangan yang dilakukan auditor harus tetap menjunjung tinggi kode etik sehingga audit bisa dilakukan secara independen. Kantor akuntan publik yang berafiliasi dengan big four, mengindikasikan auditornya dalam melaksanakan audit selalu memegang teguh kode etik sehingga potensi kecurangan yang ada di perusahaan akan mampu dideteksi dan tentunya kalau berpotensi mempengaruhi keberlangsungan perusahaanmaka, maka auditor akan memberikan opini audit going concern.

5. Opini audit tahun sebelumnya dijadikan pertimbangan dalam memberikan opini audit going concern. Kondisi ini menunjukkan bahwa opini audit tahun sebelumnya dijadikan acuan auditor dalam melakukan audit periode sekarang, sehingga jika periode sebelumnya perusahaan mendapatkan opini audit going concern, maka kemungkinan besar perusahaan akan mendapatkan opini audit going concern dengan catatan kon-disi keuangan perusahaan tidak mengalami peningkatan.

\section{Saran}

Berdasarkan pemaparan dan pembahasan hasil penelitian sebelumnya, maka saran yang disampaikan untuk penelitian selanjutnya adalah sebagai berikut:

1. Berdasarkan hasil penelitian nilai koefisien determinasi relatif kecil yaitu sebesar $13,2 \%$, sehingga penelitian terkait going concern harus melibatkan faktor-faktor lain yang lebih luas yang dapat dijadikan pertimbangan oleh auditor dalam memberikan opini audit going concern missalnya lamanya perikatan dengan kantor akuntan publik, pengendalian internal perusahaan, tata kelola perusahaan, dan faktor lainnya yang dapat mempengaruhi.

2. Penelitian selanjutnya agar memperluas scope perusahaan, tidak hanya sektor manufaktur tetapi dengan menggunakan seluruh perusahaan yang terdaftar di 
Bursa Efek Indonesia. Periode amatan sebaiknya diperpanjang minimal lima tahun sehingga dapat memberikan gambaran secara menyeluruh terhadap pemberian opini audit going concern yang diberikan oleh auditor.

\section{DAFTAR PUSTAKA}

Aiisiah, N. 2012. Pengaruh Kualitas Audit, Kondisi Keuangan Perusahaan, Opini Audit Tahun Sebelumnya, Perusahaan Terhadap Kecenderungan Penerimaan Opini Audit Going Concern. Skripsi. Fakultas Ekonomi Universitas Diponegoro. Semarang.

Al'adawiah, R., W. Julianto, dan R. Sari. 2020. Pengaruh Ukuran Perusahaan, Audit Tenur, dan Pertumbuhan Perusahaan Terhadap Opini Audit Going Concern. Jurnal Ilmiah Akuntansi Kesatuan 8(3): 349-360. https://doi.org/10.37641/ jiakes.v8i3.387

Al Fath, N. D. dan P. Sugito. 2020. Pengaruh Debt Default, Pertumbuhan Perusahaan Dan Ukuran Perusahaan Terhadap Penerimaan Opini Audit Going Concern. Buletin Studi Ekonomi, 2(1): 265. https://doi.org/10.24843/bse. 2020.v25.i02.p06

Andyny, R. D. 2017. Pengaruh Ukuran Perusahaan, Audit Tenure Dan Reputasi Kap Terhadap Opini Audit Going Concern Pada Perusahaan Manufaktur Sektor Barang Konsumsi Periode 2014-2015. Simki-Economic, 01(02): 2-12.

Dewana, G. A. 2015. Pengaruh Independensi, Kompetensi, Fee Audit terhadap Kualitas Audit dengan Etika Audit sebagai Variabel Moderating. Jurnal Bisnis Manajemen dan Ekonomi.

Effendi, B. 2019. Kualitas Audit, Kondisi Keuangan, Ukuran Perusahaan dan Penerimaan Opini Audit Going Concern. Riset Dan Jurnal Akuntansi, 3(1): 9-15. https://doi.org/10.33395/ owner.v3i1.80

Fahmi, N. 2015. Pengaruh Audit Tenure, Opini Audit Tahun Sebelumnya, dan
Disclosure Terhadap Opini Audit Going Concern. Akuntabilitas VIII(3): 162-170.

Ghozali, I. dan D. Ratmono. 2017. Analisis Multivariat dan Ekonometrika. Badan Penerbit Universitas Diponegoro. Semarang.

Ikatan Akuntan Indonesia. 2017. Standar Akuntansi Keuangan (Statement of Financial Accounting Standards). Ikatan Akuntansi Indonesia.

Jusup, H. 2014. Auditing (Pengauditan Berbasis ISA). Sekolah Tinggi Ilmu Ekonomi YKPN. Yogyakarta.

Kadirisman, I. 2018. Pengaruh Profitabilitas, Leverage, Kondisi Keuangan Dan Ukuran Perusahaan Terhadap Opini Audit Going Concern. Buletin Ekonomi 9(1): 1-14.

Kurnia, P. dan N. F. Mella. 2018. Opini Audit Going Concern: Kajian Berdasarkan Kualitas Audit, Kondisi Keuangan, Audit Tenure, Ukuran Perusahaan, Pertumbuhan Perusahaan dan Opini Audit Tahun Sebelumnya pada Perusahaan yang Mengalami Financial Distress pada Perusahaan Manufaktur. Jurnal Riset Akuntansi dan Keuangan, 6(1): 105-122. http://ejournal.upi. edu/index.php/JRAK/article/view/8 937/7437

Kusumaningrum, Y. dan Z. Zulaikha. 2019. Analisis Pengaruh Ukuran Perusahaan, Likuiditas Dan Leverage Terhadap Penerimaan Opini Audit Going Concern. Diponegoro Journal of Accounting 8(4): 1-12.

Minerva, L., V. S. Sumeisey, S. Stefani, S. Wijaya, dan C. A. Lim. 2020. Pengaruh Kualitas Audit, Debt Ratio, Ukuran Perusahaan dan Audit Lag terhadap Opini Audit Going Concern. Owner: Riset Dan Jurnal Akuntansi 4(1): 254-266. https://doi.org/10.33395/owner.v4i1. 180

Nafiatin, R. 2017. Faktor-Faktor Yang Mempengaruhi Opini Auditgoing Concern. Accounting Global Journal 1(1): 451-481. https://doi.org/10.24176/ 
agj.v1i1.3327

Pratiwi, L. dan T. H. Lim. 2018. Pengaruh Pertumbuhan Perusahaan, Audit Tenure dan Opini Audit Tahun Sebelumnya Terhadap Opini Audit Going Concern. Jurnal Riset Keuangan dan Akuntansi 4: 67-77.

Purba, S. F. dan N. Nazir. 2019. Pengaruh Pertumbuhan Perusahaan, Rasio Keuangan, Dan Kualitas Auditor Terhadap Opini Audit Going Concern. Jurnal Akuntansi Trisakti 5(2): 199-214. https:// doi.org/10.25105/jat.v5i2.523 8

Putra, D. A., A. S. H. Anwar, dan T. Nur. 2017. Pengaruh Pertumbuhan Perusahaan, Kondisi Keuangan Perusahaan, dan Opini Audit Tahun Sebelumnya Terhadap Opini Audit Going Concern. Jurnal Reviu Akuntansi dan Keuangan 6(1). https://doi.org/10. 22219/jrak.v6i1.5081

Putri, B. R. 2018. Pengaruh Profitabilitas, Likuiditas, Solvabilitas, dan Pertumbuhan Perusahaan terhadap Opini Audit Going Concern (Studi Pada Perusahaan Retail Trade yang Terdaftar di Bursa Efek Indonesia Tahun 2012-2016). Skripsi. Fakultas Ekonomi Dan Bisnis Universitas Islam Negeri Syarif Hidayatullah, 1-106. Jakarta.

Rahman, M. A. dan H. Ahmad. 2018. Pengaruh Likuiditas, Profitabilitas, dan Solvabilitas Terhadap Opini Audit Going Concern. Jurnal Akuntansi 1(2): 44-55.

Rahmawati, D., E. D. Wahyuningsih, dan I. Setiawati. 2018. Pengaruh Likuiditas, Ukuran Perusahaan, Pertumbuhan Perusahaan, dan Opini Audit Tahun
Sebelumnya Terhadap Opini Audit Going Concern (Studi Empiris Perusahaan Manufaktur yang Terdaftar di Bursa Efek Indonesia). Maksimum Media Akuntansi Universitas Muham-madiyah Semarang 8(2): 67-76. https://doi.org/10.26714/mki.8.2.201 8.67-76

Rakatenda, G. N. dan I. W. Putra. 2016. Opini Audit Going Concern dan FaktorFaktor yang Mempegaruhinya. EJurnal Akuntansi Universitas Udayana 16(2): 1347-1375.

Putri, Y. R., Hardiwinoto, dan Alwiyah. 2019. Pengaruh Ukuran Perusahaan, Debt Default, Disclosure, Opini Audit Tahun Sebelumnya, dan Pertumbuhan Perusa-haan Terhadap Penerimaan Opini Audit Going Concern (Pada Perusa-haan Manufaktur Industri Dasar Dan Kimia Di Bursa Efek Indonesia Tahun 2013-2017). Maksimum Media Akuntansi Universitas Muhammadiyah Semarang 9(1): 63-80. https://doi.org/10.26714/mki.8.3.201 8.63-80

Supriyadi, Y. 2018. Pengaruh profitabilitas, likuiditas, dan pertumbuhan perusahaan terhadap penerimaan opini audit going concern. Skripsi. Universitas Trisakti. Jakarta.

Wati, K. K., G. A. Yuniarta, dan N. K. Sinarwati. 2017. Pengaruh Ukuran KAP dan Opini Audit Tahun Sebelumnya Terhadap Opini Audit Going Concern Dengan Kondisi Keuangan Sebagai Variabel Moderating. E-Journal Nama Jurnal Universitas Pendidikan Ganesha Jurusan Akuntansi Program S1 7(1): 1-12. 